\title{
FURADANTIN IN PROTEUS BACILLURIA PRELIMINARY COMMUNICATION
}

\author{
BY
}

\author{
S. J. HEFFERNAN, P. W. KIPPAX, AND W. A. V. PAMPLIN \\ From St. James's Hospital, Balham, London
}

(RECEIVED FOR PUBLICATION OCTOBER 15, 1954)

The widespread use of antibiotics has increased the importance of resistant pathogens. Unmasked infections due to organisms such as Candida (Rankin, 1953), Pseudomonas, and Proteus (Yow, 1952) are presenting therapeutic problems. The search for new substances with which to treat such infections is therefore amply justified.

Nitrofurantoin is one substance which has been investigated in the U.S.A., and several reports on its efficacy have been published (Norfleet, Beamer, and Carpenter, 1952; Mintzer, Kadison, Shales, and Felsenfeld, 1953; Carroll and Brennan, 1954). Nitrofurantoin is $\mathrm{N}$-(5-nitro-furfurylidene 1-aminohydantoin). It is soluble in water to the extent of $18 \mathrm{mg}$. per $100 \mathrm{ml}$. at $p \mathrm{H} 7$. It is administered orally. Forty per cent. of the administered dose is excreted in the urine (Mintzer et al., 1953) and the rapidity of excretion necessitates six-hourly administration.

As a small supply of this substance became available in the form of "furadantin," it was decided to employ it in an attempt to assess its efficacy against Proteus. Cases of Proteus bacilluria were chosen, not because it was felt that such conditions are of outstanding gravity, but because the drug is largely excreted in the urine where it may be expected to exert a strong effect.

\section{Material and Methods}

Selection of Cases.-Cases selected were either patients who had undergone retropubic prostatectomy for benign prostatic hypertrophy whose catheter had been removed, or patients under treatment for postprostatectomy stricture, or under hormone treatment for carcinoma of the prostate.

Cases of infections with strains of Proteus resistant to $5 \mathrm{mg}$. per ml. "furadantin" in vitro were rejected, though one such case served as a control in Group I.

Control cases were selected from similar groups in the same ward, and were treated with a high fluid intake only.

No attempt at random sampling was made. Cases were designated " test" and "control" arbitrarily.
Dosage.-The recommended dosage is $5-8 \mathrm{mg}$. per kg. body weight, which approximates to $100 \mathrm{mg}$. sixhourly in the weight range 170-250 lb. It was decided to use this standard dose for all our cases, and, since supplies of "furadantin" were limited, to treat cases for five days only.

One of our patients complained of diarrhoea on the fifth day of treatment. No other evidence of toxicity was encountered.

Isolation.-Early morning mid-stream specimens of urine were used, taken with the usual antiseptic toilet. A centrifuged deposit was examined microscopically for cells and organisms and cultured on McConkey's medium and on blood agar containing "dispersol L.N." to prevent swarming (Mackie and McCartney, 1948).

By this technique results could only be assessed in such terms as " heavy growth," "light growth," and so on. Nevertheless, there was clinical evidence of improvement in spite of failure to sterilize the urine and therefore approximate viable counts were undertaken in the later stages of the experiment (Group II). Again early morning mid-stream urines were used. These were refrigerated at $4^{\circ} \mathrm{C}$. immediately after collection, and examined as rapidly as possible after removal from the refrigerator, in order to minimize bacterial multiplication. Tenfold serial dilutions of the urine samples were made in sterile physiological saline, down to 1 in 1 million. Of these dilutions a standard $4 \mathrm{~mm}$. loopful was then plated on blood agar containing " dispersol L.N." Colonies were counted after overnight incubation at $37^{\circ} \mathrm{C}$.

Identification.-Identification of Proteus was based on the usual cultural, morphological, and biochemical criteria (Wilson and Miles, 1946; Kauffmann, 1951; Cooke, 1948). Urease production was tested on Christensen's medium.

Sensitivity.-A tube dilution method in nutrient broth was tried at first, but was abandoned owing to difficulty in dissolving "furadantin" to produce a suitable stock solution.

A range of $2 \mathrm{ml}$. nutrient agar slopes in bijou bottles was therefore prepared by adding a stock suspension of " furadantin" ( $50 \mathrm{mg}$. per $\mathrm{ml}$.) in sterile distilled water in amounts small enough not to interfere materially with the strength of the gel, the stock solution being diluted as required for the lower concentrations. By 
trial and error it was found that $0.5,1$, and $5 \mathrm{mg}$. per $\mathrm{ml}$. final concentrations of " furadantin" in nutrient agar covered the range of sensitivity of most strains of Proteus encountered. These were the concentrations used.

After preparation, the slopes were refrigerated for 24 hours to permit diffusion, and subsequently stored at refrigerator temperature if not required for immediate use.

In testing sensitivity of Proteus strains, the inoculum was one $4 \mathrm{~mm}$. loopful of a five- to six-hour growth of the organism in digest broth, spread on the surface of the agar slope. Reading was done after 18 hours' incubation at $37^{\circ} \mathrm{C}$. and was reported simply as " growth" or " no growth," visible with a hand lens or naked eye. No attempt was made to distinguish between bacteriostatic and bactericidal effects.

\section{Results}

Clinical.-In the Proteus infections studied in this series no characteristic syndrome emerged. Some infections were symptomless; in others, patients reported nocturnal frequency and scalding micturition, and remission in these during treatment was accepted as clinical evidence of improvement.

Results were assessed in 12 cases by careful questioning (Table 1).

TABLE I

RESULTS IN 12 CASES

\begin{tabular}{c|l|c}
\hline $\begin{array}{c}\text { Antecedent } \\
\text { Condition }\end{array}$ & \multicolumn{1}{c|}{$\begin{array}{c}\text { Clinical } \\
\text { Response }\end{array}$} & $\begin{array}{c}\text { No. of } \\
\text { Cases }\end{array}$ \\
\hline Post-prostatectomy $\quad \cdots$ & $\begin{array}{l}\text { Symptom-free at end of course } \\
\text { Improved } \\
\text { Unchanged }\end{array}$ & 6 \\
1 \\
$\begin{array}{l}\text { Post-prostatectomy-stric- } \\
\text { ture or carcinoma of } \\
\text { prostate }\end{array}$ & $\begin{array}{l}\text { Improved } \\
\text { (These four cases relapsed } \\
\text { clinically after the end of the } \\
\text { course of " furadantin") }\end{array}$ & 4 \\
\hline
\end{tabular}

Bacteriological.-From this point of view the cases fall into two groups:

Group I: No quantitative estimate of Proteus bacilluria made.

Group II: Quantitative estimate made.

Group I.-These results are not reported in detail, since little consistent change was detected during treatment.

Group II.-Detailed consideration of colony counts shows a falling off in numbers in the test group (Table II) compared with the controls (Table III). For brevity, results are shown as numbers of patients in whose urine colony counts of less than 30 per plate were seen. In most instances, those plates showing more than 30 colonies were quite uncountable, but most of those showing less than 30 showed none.
TABLE II

\begin{tabular}{|c|c|c|c|c|c|c|c|}
\hline \multirow{2}{*}{$\begin{array}{l}\text { Dilution } \\
\text { of Urine }\end{array}$} & \multicolumn{5}{|c|}{$\begin{array}{c}\text { Day of } \\
\text { Treatment }\end{array}$} & \multicolumn{2}{|c|}{ 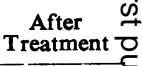 } \\
\hline & 1 & 2 & 3 & 4 & 5 & 6 & 7 음 \\
\hline $\begin{array}{ll}1 / 10 \\
1 / 100 \\
1 / 1,000 \\
1 / 10,000 \\
1 / 100,000 \\
1 / 1,000,000\end{array}$ & $\begin{array}{l}1 \\
1 \\
1 \\
1 \\
1 \\
1\end{array}$ & $\begin{array}{l}1 \\
1 \\
2 \\
2 \\
3 \\
3\end{array}$ & $\begin{array}{l}1 \\
1 \\
1 \\
2 \\
2 \\
3 \\
3\end{array}$ & $\begin{array}{l}2 \\
2 \\
3 \\
3 \\
3 \\
3\end{array}$ & $\begin{array}{l}1 \\
1 \\
2 \\
3 \\
3 \\
3\end{array}$ & $\begin{array}{l}1 \\
1 \\
1 \\
2 \\
2 \\
2\end{array}$ & $\begin{array}{lll}1 & \frac{1}{7} \\
1 & 0 \\
1 & 0 \\
1 & 0 \\
1 & 0 \\
1 & 0\end{array}$ \\
\hline Total examined & 3 & 3 & 3 & 3 & 3 & 2 & 2 \\
\hline
\end{tabular}

TABLE III

COLONY COUNTS IN CONTROL CASES

\begin{tabular}{|c|c|c|c|c|c|c|c|}
\hline \multirow{2}{*}{\multicolumn{3}{|c|}{ Dilution of Urine }} & \multicolumn{5}{|c|}{ Day of Observation } \\
\hline & & & \multirow{2}{*}{$\begin{array}{l}1 \\
0 \\
0 \\
0 \\
1\end{array}$} & $\begin{array}{l}2 \\
0\end{array}$ & \multirow{2}{*}{$\begin{array}{l}3 \\
0 \\
0 \\
0 \\
0 \\
0\end{array}$} & \multirow{2}{*}{$\begin{array}{l}4 \\
0 \\
0 \\
0 \\
0 \\
1\end{array}$} & \multirow[b]{2}{*}{$\begin{array}{l}0 \\
0 \\
1\end{array}$} \\
\hline $\begin{array}{ll}1 / 10 & . \\
1 / 100 & \cdots \\
1 / 1,000 & \cdots \\
1 / 10,000 & \cdots \\
1 / 100,000 & \\
1 / 1,000,000\end{array}$ & $\begin{array}{l}\because \\
\because\end{array}$ & $\begin{array}{l}\because \\
\cdots \\
\cdots \\
\cdots \\
\cdots\end{array}$ & & \begin{tabular}{|c|}
0 \\
0 \\
0 \\
1 \\
counted \\
Not \\
counted
\end{tabular} & & & \\
\hline Total exami & & $\cdots$ & 2 & 2 & 2 & 2 & 2 \\
\hline
\end{tabular}

Sensitivities.-These were expressed as " growth or " no growth" at the concentrations testech" Fifty-three cultures of Proteus isolated from urine were tested in order to arrive at some sort of sensitivity base line. Of these, 44 were sensitive to $1 \mathrm{mg}$. per $\mathrm{ml}$. and resistant to $0.5 \mathrm{mg}$. per $\mathrm{ml} \stackrel{乛}{?}$ six were sensitive to $0.5 \mathrm{mg}$. per mil. and resistan to $0.1 \mathrm{mg}$. per $\mathrm{ml}$.: three were resistant to $5 \mathrm{mg}$ per $\mathrm{ml}$.

Strains.-Forty-eight of the strains tested fow sensitivity were typed biochemically, using reactions with mannite, maltose, gelatin, and sucrose, and their production of $\mathrm{H}_{2} \mathrm{~S}$ and indole.

Of these, seven were Vulgaris, two Mirabilis, on Morganii, eight Rettgeri, and the remainder atypicat The 30 atypical strains fell into groups, consistent within themselves, containing organisms not neces sarily isolated from one patient only. It is hoped to investigate these biochemically atypical strains further at a later date.

No clear relation between biochemical type and sensitivity to "furadantin" was observed.

\section{Discussion}

The assessment of a method of treatment for Proteus bacilluria is complex. Clinical metho tend to be subjective, since no characteristic sy $\overrightarrow{8}-$ drome is seen, and, indeed, infections may symptomless. 
Bacteriological methods are more objective, though there are many problems. Special methods are essential to ensure that Proteus does not multiply excessively in the sample before it is tested in the laboratory. With experimental courses of treatment, if complete cure is not obtained, quantitative methods of assessment are necessary. Preliminary testing in our series has shown that more than one biochemical strain or variant of Proteus may be recovered from a single urine from a case of Proteus bacilluria, and the possibility that one of these strains is resistant to "furadantin" has not yet been explored.

With these reservations, it is considered that the test cases in Group II show a striking difference from the controls, though at present both are few.

It is possible that longer courses of treatment might give more clear-cut results.

It is hoped to provide serological confirmation for the isolation of a high proportion of biochemically atypical strains of Proteus. No attempt was made to identify Providence strains, since rapid urease production was accepted as a criterion of Proteus for the purpose of the experiments.

Furadantin appears to exert some beneficial effect on Proteus bacilluria, and merits further trial in this condition.

\section{Summary}

Twelve cases of Proteus bacilluria were treated with "furadantin" for five days. At the end of this period six patients were symptom-free, five were improved, and one was unchanged.
Eight of these cases were assessed bacteriologically, three of them by a rough quantitative method. Those tested quantitatively showed bacteriological evidence of improvement.

None of five control cases observed for periods of five days showed clinical or bacteriological evidence of clearing or remission of the infection.

Fifty-three cultures of Proteus isolated from urines were tested for sensitivity to "furadantin," and results are reported.

Forty-eight of these strains were typed biochemically. Of these 30 were biochemically atypical, but fell into several groups homogeneous within themselves.

We wish to express our indebtedness to Mr. H. K. Vernon, consultant surgeon, St. James's Hospital, Balham, for access to clinical material, and to Messrs. Duncan, Flockhart \& Co. (Edinburgh and London) for supplies of " furadantin."

\section{REFERENCES}

Carroll, G., and Brennan, R. V. (1954). J. Urol., 71, 650.

Cooke, G. T. (1948). J. Path. Bact., 60, 171.

Kauffmann, F. (1951). Enterobacteriaceae. Munksgaard, Copenhagen.

Mackie, T. J., and McCartney, J. E. (1948). Handbook of Practical Bacterioiogy, 8th ed. Livingstone, Edinburgh.

Mintzer, S., Kadison, E. R., Shales, W. H., and Felsenfeld, O. (1953). Antibiot. and Chemother., 3, 151.

Norfleet, C. M., Beamer, P. R., and Carpenter, H. M. (1952). J. Urol., 70, 113.

Rankin, N. E. (1953). Brit. med. J., 1, 918.

Wilson, G. S., and Miles, A. A. (1946). In Topley and Wilson's Principles of Bacteriology and Immunity, 3rd ed. Arnold, London.

Yow, E. M. (1952). J. Amer. med. Ass., 149, 1184. 